Article

\title{
Path toward a Child-Centered Approach in the Czech Social and Legal Protection of Children
}

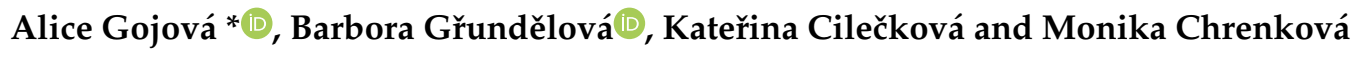 \\ Faculty of Social Studies, University of Ostrava, Českobratrská 16, 70200 Ostrava, Czech Republic; \\ Barbora.Grundelova@osu.cz (B.G.); Katerina.Cileckova@osu.cz (K.C.); Monika.Chrenkova@osu.cz (M.C.) \\ * Correspondence: Alice.Gojova@osu.cz; Tel.: +420-734-358-607
}

Received: 25 September 2020; Accepted: 23 October 2020; Published: 27 October 2020

\begin{abstract}
Child protection was traditionally based on a presumption that the mother best knows what is in the best interest of her child. The discourse began to be questioned in the Czech Republic in the 1990s, followed by efforts to bring interests and needs of children into focus, as well as the ways in which they can be taken into account in the assessment process as a basis for intervention. This paper aimed to identify key features of the child-centered approach in the professional discourse of the Czech child protection and to analyze the conditions of its application. The goal was achieved through qualitative thematic analysis of professional texts in the area of social and legal protection of children since 1990 and also of legislative and methodological materials regulating child protection. This paper shows the changing of the paradigm in the social and legal protection of children and points out the shortcomings in social work practice. The reason for optimism may be the fact that an umbrella body of state administration for child protection is aware of shortcomings and, in the form of projects focusing on various topics of social work with families, works to improve competences and knowledge.
\end{abstract}

Keywords: social and legal protection; child protection; child-centered approach; qualitative thematic analysis

\section{Introduction}

A child in need is traditionally perceived as a passive object of protection and care. This "protective discourse" may underestimate or overlook the child's own potential, abilities, and resources, which may actually lead to the nonfulfilment of his or her best interests [1]. In recent decades, child welfare services have emphasized a reorientation from protective child protection to a more holistic, preventative, and family focused orientation [2-7] based on a strengths-based family-centered model of practice $[7,8]$. The family-centered approach to child welfare was critically discussed at the beginning of the 21st century, especially in connection with its emphasis on preserving the family, which may not always be fully in line with the best interests of the child [9]. Therefore, in the international context, a child-centered approach has recently been promoted, with the child being perceived as an independent subject with his or her own interests and rights [10-12]. This new perception of the child's position in the system of child protection and welfare brings new challenges for setting up the whole system and for the work of social workers. This paper aimed to monitor the development of professional discourse in the area of social and legal protection of children in the Czech Republic (hereinafter CZE), in particular we focused on the features of the child-centered approach and analysis of its application conditions. 


\section{Theoretical Background}

\subsection{Child Protection Approaches}

Child protection is generally understood as a commitment of the state to protect the child's interests. In a more narrow sense, it is about protecting children from the risk of mistreatment and, more broadly, it is about providing equal opportunities for all children in society [13]. What is considered a trigger for state intervention in family life differs in each national context $[14,15]$.

In the European context, professional social work plays an important role in the reform of child protection services [16-18]. If a family comes into contact with child protection workers, it is often the mother who becomes their client [19-21]. Mothers are viewed as a "decisive variable" in child welfare services. Social workers can thus succumb to the motherhood mystique, that is, a view of motherhood that believes that women are uniquely suited to raising children, that all women want to be mothers, and that motherhood is the ultimate fulfilment of women's life [22]. In practice, this manifests itself in the fact that social workers may mistakenly assume that women are by nature better parents than men, and that the mother is a priori more important to the child than the father [23]. If the mother does not meet stereotypical expectations of a "good mother" [24], she is perceived as failing her role [25]. Social work interventions in a family environment are then often aimed at supporting motherhood [26]. This can lead to female workers focusing more on the needs of mothers than children, while children are considered incompetent [11]. Men are left out of interventions and the attention of social workers [27,28]. The situation is described in the literature as "responsible mothers, invisible men" $[29,30]$. Research has shown that involving clients in decision-making is a more ethical and effective model of practice [31], however, parents and children find themselves on the fringes of a child protection process and have limited opportunities to participate, despite professionals' efforts to involve the entire family [32].

D'Cruz [33] emphasized that focusing on risk factors and neglect puts child protection workers in the position of those who protect children from carers posing potential threat to children. According to Scourfield [27], child protection workers perceive men in particular as a threat, as sexually abusive and violent men. According to him, sexual abuse has had a major impact on the social work culture in recent years, and he refers to a "predatory paedophile discourse" in child protection services, adding that social workers are expected to reveal potential sexual abuse. As a manifestation of this approach, the workers seek to minimize the risks in the child's environment. This method is oppressive rather than constructive [34], thus not allowing, for example, for the establishment of a relationship that is essential for the practice of social work [35].

One of the responses to the problems associated with risk-focused strategies was the assertion of family-centered, prevention- and strength-based models of practice. The family-centered orientation in child protection emphasizes a focus on children's needs and safety in the context of their families, whose reunification and strengths are to be supported $[7,8]$.

Recently, the child-centered approach has been increasingly applied in the area of child protection, and this is associated with a theoretical shift in studies of childhood, where children are not perceived only as passive recipients of socialization by adults, but as social actors, as a subject who has the right and ability to present their view of their life situation [36], who participates and is involved in decisions about their own lives [1]. "Child-focused child protection approach is the one in which children's interests are not always seen as closely identified with the interests of their parents, and children are seen as independent rights holders" [37] (p. 829). Pösö, Skivenes and Hestbæk [38] have documented a number of cases where the decision was made in the child interests and not in the interests of the family as a whole.

In his conceptualizing of the child-centered approach, Skivenes [13] distinguished between three aspects: (1) children's legal rights and organizational procedures, (2) the recognition of children by adults as individuals with specific interests and needs, and (3) the use of the child's individual perspective as a way of interpreting what the world means to children. The main principle of the child-centered approach is the child's right to express him/herself toward the circumstances of his or her 
life, that is, the child's involvement and participation in the assessment process and the interventions of child and family welfare services [39]. D'Cruz and Stagnitti [10] combined this approach with collaborative professional practice, which is based on a professional and carer relationship and dialogue. The core of this dialogue should be the well-being of the child, and the child should be included in the dialogue. A characteristic feature of the approach is a focus on the needs, interests, and wishes of the child during the intervention [39]. The child-centered approach focuses on supporting the child's own abilities and resources and makes his or her participation a basic mechanism of help and support [1].

However, participation of children is still a difficult requirement in practice [40]. Difficulties in involving children in participatory practice are mainly based on the competence of social workers and attitudes to children's participation, organizational structures, material design of offices, or guidelines that represent barriers to children's participation [41].

\subsection{Social and Legal Protection of Children in CZE}

Specific interest in the family and the child was part of the government's policy during socialism, i.e., before 1990. The groups cared for included children with special learning needs, children with disabilities, children living in an environment with a high crime rate or where they committed crime themselves, and children from divorced marriages and in foster care. Like it had on everything else, the state had a monopoly on social work with family and children and carried it out through district and regional national committees [42].

A fundamental change in the CZE after 1990 was the adoption of the Convention on the Rights of the Child (hereinafter also the Convention), which became part of the Czech legal system in 1991. The Convention and the rights of children contained therein are conceived from various theoretical perspectives. A frequently discussed topic in the Czech professional literature is [43], whether a child is an object of care or a full subject of a legal relationship. According to the Convention, a child is clearly considered to be the subject of a legal relationship. The provision, which has also become an interpretative rule, is Article 3 of the Convention: "The best interests of the child shall be of a primary consideration in all activities concerning children, whether carried out by public or private social welfare institutions, courts, administrative or legislative authorities." Another key concept in the Convention is the well-being of the child. The content of the Convention can be used to deduce the mutual relationship of the essence of the above listed concepts. Without any doubt, it can be stated that respecting the "best interests of the child" is the right way to achieve the "well-being" of the child. The concept "well-being" is considered to be the aim of all legal proceedings concerning a child [44].

The Convention does not define what the best interests of the child are; however, they should be the essence of every decision about a child. An abstract definition of the "best interests of the child" is not possible; it is always an output of a specific situation. In decision-making practice, it is precisely this principle that should fulfil a balancing (measuring) function in conflicts between specific human rights, mediating the resolution of conflicts between such subjective rights, naturally including the rights of the child [45]. As such, it is used in the application practice of courts and can be applied in the same manner within the social and legal protection of children [46,47].

The Ministry of Labor and Social Affairs (hereinafter MoLSA), which is the highest administrative body ensuring the social and legal protection of children, conceives the best interests of the child as a comprehensive and dynamic concept containing three components:

(a) The fundamental right of the child - the best interest is assessed and taken in to account.

(b) Interpretation principle-if it is possible to interpret a legal regulation in multiple ways, the one that most effectively fulfils the best interests of the child shall be chosen.

(c) Procedural rule-whenever a decision is made that could affect the child, it is necessary to assess what positive or negative effects the decision may have on the child.

In assessing the best interests of the child, the child's opinion, identity, preservation of the family environment and relationships, childcare, protection and safety, the child's vulnerability, health, and the 
right to education should be taken in to account. The context of the best interests of the child is also taken into consideration. The first component is the personality of an adult caring for the child or making decisions for the child (guardian, judge, etc.). It is based on the assumption that only a stable personality with a loving attitude towards children is able to understand and respect the best interests of the child. Seeking a child's opinion requires the ability to create a sense of security and trust, an effort to look at things from a child's perspective. The second component is the cultural context; the concept of the best interests of the child is not fulfilled in a paternalist culture that focuses on the interests of adults and does not give any autonomy to the child, does not consider a child a rational person capable of expressing his or her own interest, and always prioritizes the opinion of adults over the opinion of the child $[48,49]$.

We present the above information as a minimum theoretical framework on the basis of which the applicable Czech legislation has been adopted and also applied. The basic legislation concerning child protection is Act No. 359/1999 Coll., the Act on Social and Legal Protection (hereinafter SLP Act), which underwent a significant amendment on 1 January 2013. The reason for the adoption of the SLP Act was mainly the need to separate the issue of children's rights from social care and to define the activities of state administrative bodies towards the protection of children's rights in line with the constitutionally guaranteed special protection of the child anchored in the Charter of Fundamental Rights and Freedoms and in international treaties. The main principles of the SLP Act include the principle of preventive activities affecting problematic family relationships. The law also enabled the establishment of organizations authorized with the performance of social and legal protection of children [50]. This law was expected by the professional public and received a positive adoption; its amendment in 2013 strove mostly toward strengthening and professionalizing foster care, with the goal of reducing the number of children in institutional care.

Another important legal regulation ensuring children's rights is Act No. 89/2012 Coll., the Civil Code, particularly the second part devoted to family law. The specific status of children is reflected in Act No. 218/2003 Coll., on the responsibility of youth for illegal acts and on juvenile justice. The material security of children is regulated by legislation on social benefits and allowances to families in specific situations.

The principle of the best child's interests was, in its original essence, a manifestation of state paternalism in the sense of protecting a legally incapable object. It is currently facing the question of how to resolve the conflict with the child's right to express his or her views and to have his or her views taken in to account when deciding on his or her future. In the proceedings that directly concern a minor, he or she cannot be regarded as a mere object about which others decide or be viewed as a passive observer of events, but must be perceived as an important subject of law and party to the proceedings, and thus to be approached that way. The child's right to be heard is understood more broadly than as a mere opportunity to express his or her views on the issue under review. This right must also be interpreted in the context of a more general right to be present at the hearing and to be seen as an important guarantee that children's rights are not to be decided upon without their participation [51]. The basis for participation is contained in Article 12 of the Convention, which guarantees the child that if he or she is able to formulate his or her own views, he or she has the right to express them freely; the child's views must be given due consideration according to the age and level of the child; the child must be heard in any judicial or administrative proceedings concerning his or her life. The Convention does not set a minimum age limit for the obligation of a court or administrative authority to hear a child in the proceedings. Under European Union law, children's participation right is guaranteed by the EU Charter of Fundamental Rights, the European Convention on the Exercise of Children's Rights [52], and the Brussels II bis. Regulation [53].

In Czech law, the child's participation right is enshrined in several legal regulations. Primarily, in the Civil Code there is an age limit of 12 years, from which the child is considered intellectually mature such that the court can provide him or her with the necessary information so that the child can form his or her own opinion and communicate that opinion. Therefore, a child of this age and older 
will be heard by the court in person, while a younger child will be heard by a child welfare authority, or in another suitable manner. Even a younger child can be heard by the court in person, and the court pays due attention to the child's opinion [54]. The procedural regulation is contained in the Code of Civil Procedure, the Act on Special Judicial Proceedings, and the SLP Act. Both international and Czech legislation in principle create a complementary whole and establish a sufficient framework for the child's participation [55]. Despite absolutely sufficient legislation, the participation right of children who are parties to court proceedings concerning the care of them in the event of divorce or separation of parents is implemented only sporadically [56].

The Constitutional Court of the CZE plays a crucial role in the application of children's participation right into judicial and administrative practice. In case law, from the general courts it demands respect for the best interests of the child, the participation rights of the child and their quality representation in court proceedings. It must not be overlooked that a court decision should be properly and comprehensibly explained to the child, especially if his or her views and wishes have not been complied with [57]. It needs to be emphasized that the Constitutional Court deals with the issue of children's participation rights in its decision-making practice precisely because it has not been sufficiently taken in to account and implemented in the practice of general courts.

\subsection{Background for Implementation of the Analysis}

It was the knowledge of the difference between the legislative framework and the practice of social and legal protection of children that drew our intention to write this paper. We believe that the professional discourse and methodologies of an administrative body providing social and legal protection of children (MoLSA) have a significant impact on the execution of practice. They also testify about the practice, and then research results retroactively shape it. In the center of our attention are the features of the child-centered approach, in the application of which CZE is clearly bound by the legislative framework of child protection. Our analysis was written in 2018-2020 in connection with the project Social Adjustment of Homeless Children with Domestic Violence Experience in the Territory of the City of Ostrava, supported by the Czech Science Foundation. Its purpose was to map the contextual framework of social adjustment of vulnerable children and to create an overview of research results on the topic of exposing children to the threat of homelessness and domestic violence.

\section{Methods}

This paper aimed to identify features of the child-centered approach in the professional discourse of Czech child protection and to analyze the conditions of its application. The goal has been achieved through qualitative thematic analysis of professional texts in the area of social and legal protection of children, as well as legislative and methodological materials regulating child protection in CZE. The thematic analysis was driven by 4 research questions:

RQ1: How is a child's role understood and described in professional texts in the area of social and legal protection of children?

RQ2: How are reasons for social and legal protection of children understood in the texts?

RQ3: How is the objective of social and legal protection of children understood in the texts?

RQ4: How is the process of assessment and intervention in the area of social and legal protection of children understood and described in the texts?

To implement our research, we chose qualitative thematic analysis [58]. We searched three different professional journals (Sociální práce/Sociálna práce-ISSN 1213-6204, Sociální pedagogika-ISSN 1805-8825, and Kontakt-ISSN 1212-4117) for professional texts. These were texts published between 2000 and the present. In order for a text to be included in the dataset, it had to contain at least one of the following keywords: social and legal protection of children, protection of children, family and child welfare services, social work with children and families, vulnerable family, vulnerable child, assessment of child needs/child situation, individual child protection plan, child's and family's strengths, 
children participation. We also looked for methodological materials that regulate the execution of child protection at the national level. We have also included in this category monographs dealing with this topic, which are generally referred to in the area of child protection and were published by recognized, professional authorities.

The dataset was created by 71 professional articles and studies from the listed journals, 4 methodological materials for the area of child protection created or guaranteed by the relevant guarantor, i.e., the Ministry of Labor and Social Affairs, and 3 monographs that were published on the topic. An overview of texts by date of publication and main topics is given in Table 1. The table shows that the quantity of texts devoted to child protection system has been increasing recently. The methodological materials were mainly devoted to the evaluation of children's needs and the assessment of the threat to the child and his/her family.

Table 1. Overview of analyzed articles by date of publication and topic.

\begin{tabular}{|c|c|c|c|c|c|c|c|c|}
\hline $\begin{array}{c}\text { Topic } \\
\text { Date of Publication }\end{array}$ & $\begin{array}{l}\text { Substitute Family } \\
\text { (Foster) Care }\end{array}$ & $\begin{array}{l}\text { Socially Pathological } \\
\text { Phenomena }\end{array}$ & Divorce & Methods & $\begin{array}{l}\text { Children's } \\
\text { Rights }\end{array}$ & $\begin{array}{l}\text { Child Welfare } \\
\text { System }\end{array}$ & Other & Total \\
\hline $2000-2009$ & 3 & 5 & 1 & 13 & 0 & 0 & 3 & 25 \\
\hline $2010-2015$ & 4 & 4 & 0 & 13 & 1 & 2 & 1 & 25 \\
\hline $2016-2020$ & 3 & 3 & 1 & 7 & 1 & 6 & 0 & 21 \\
\hline Total & 10 & 12 & 2 & 33 & 2 & 8 & 4 & 71 \\
\hline
\end{tabular}

We used theoretical thematic analysis, which was driven by the researcher's analytical interest in the child-centered approach conducted within the constructionist framework. Based on the theoretical background, in the analysis we focused mainly on understanding the position of the child in child protection, the goals and tools of child protection, and the assessment methods. First, we started creating initial codes; our coding was theory-driven, as mentioned above. After coding, we focused our analysis at the level of themes, assembling a thematic map. In the analysis, we cite the primary data sources.

\section{Results of Thematic Analysis}

The thematic map (Table 2) shows the main categories created by coding. We could classify the data according to how the texts dealt with the question of the child protection subject, whom they perceived as the main client, how they perceived the reasons for child protection, its goals, with what purpose and how the assessment takes place, and what types of intervention they prefer and how the system of child protection should look. In the data we found relationships between individual categories. According to our findings, the key aspect is which unit is understood as to which we should focus attention in child protection, and how its role (object/subject) is understood. The collected data helped us identify four basic concepts: (a) a child as an object of protection from a dysfunctional family, (b) a vulnerable child and child's family as an object of protection, (c) a child and child's family as a subject of protection, (d) a child as a subject of protection. These concepts are constituted by how the reasons for protection are understood, from which goals of protection, assessment of the child's situation, and choice of intervention type are derived. It all has implications for setting up the entire child protection system, constructing specific topics. Individual identified models will be explained in more detail herein. We are aware that models are a reduced reflection of social reality, which they structure and simplify. The aim is to illustrate and explain its functioning in a broader socio-cultural context. According to Slavík et al. [59], models have a heuristic function and help us see social reality in a new way. In practice, the identified models overlap and permeate, but, to some extent, condition each other. Above all, the critique of the limits of individual models gives an impulse for the development of new models. 
Table 2. Thematic map of the Czech child protection discourses.

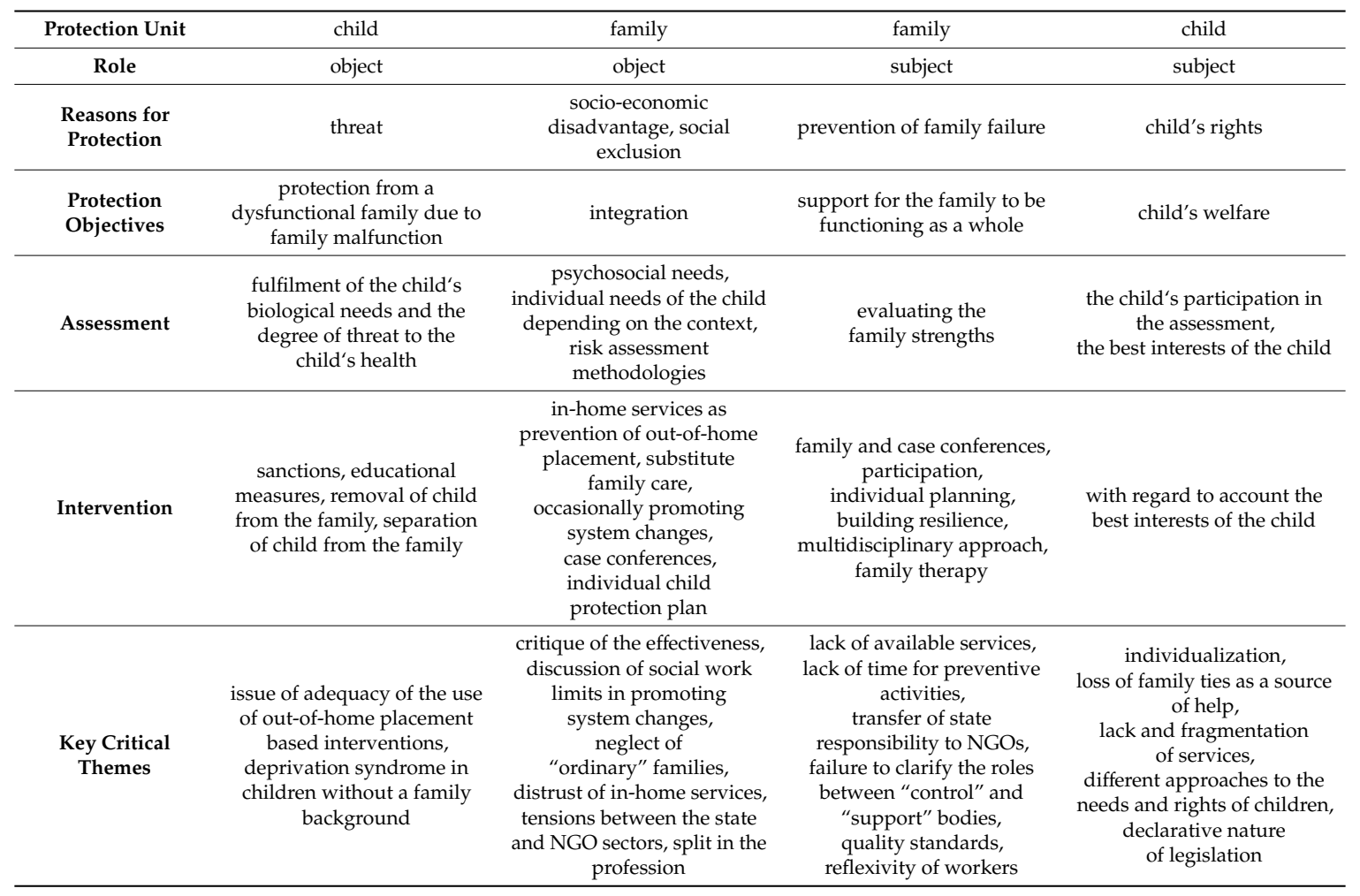

\subsection{A Child as an Object of Protection from a Dysfunctional Family}

In this conception, a child becomes an object of child protection because of a threat. A child is threatened by insufficient family background or even "bad influences" of the family [60]. The term "socially orphaned child" is used [61]. The instrument of child protection becomes primarily the order of an educational measure, which is supervision of the social and legal child protection authority over the child's upbringing or placement in institutional care, i.e., separation of the child from the family [62] to replace the so-called "bad family" with a "better home and education" [60]. The primary criterion for assessing the child's situation is the meeting of biological needs and possible health threats [62]; the term diagnosis is used [63]. This model is characterized by strong gender determinism, emphasizing biological motherhood, which is idealized and considered an absolute and unconditional value [64]. The 'motherhood mystique' affects the social worker's approach to their female clients and represents a specific feature of the organization's culture [61]. Subsequently, a weak maternal attachment to the child is perceived as the main reason for leaving the child and consenting to his or her placement in institutional care [60]. The overuse of institutional care has been gradually criticized with reference to the psychological deprivation of children, as the psychosocial needs of children have also come to the fore $[60,63,65,66]$. Šišláková [67] added that the form and degree of satisfaction of children's biological needs is culturally conditioned. She made a reference to Roma children who, from the point of view of the majority, are considered neglected, are on an unsuitable or insufficient diet, and live in unsatisfactory conditions. In the 1990s, Roma children accounted for up to one quarter of the children in institutional care [60], and according to Krátká [68] even up to half.

\subsection{A Child at Risk and the Family as an Object of Protection Against Disadvantage}

The needs assessment should not end with physiological needs, but only begin. In addition to biological needs, psychosocial needs are coming to the fore, and the need to deal with the individual needs of children is being promoted $[60,63,65,69]$. Gradually, as a result of this discussion, the concept of "vulnerable" or "disadvantaged" children [62], which are children living in institutional care, 
with a disability or from a disadvantaged socio-cultural background, comes to the fore. In this model, the removal of a child to an institutional facility also becomes a threat. The family is associated with characteristics such as problematic, dysfunctional, nonfunctional, multiproblem, vulnerable, or at risk [70].

In addition to solving internal problems of the family, child protection also focuses on supporting the integration of children by overcoming or compensating for their exclusion $[62,68,71]$. The main types of interventions include family rehabilitation, the central motif of which is the prevention of out-of-home placement of the child [66], or the provision of in-home services, for which, however, there is a persisting distrust in the population [71].

There are two important entities in the field of child protection, which are municipal child protection departments and providers of socio-activation services for families with children (especially nongovernmental nonprofit organizations). Disputes between individual entities are becoming an issue, the core of which is mutual sharing of information and confidentiality [72]. Topinka [73] stated that the central position of municipal child protection departments causes some participants in the service network to be located on its edge and to become isolated. Divoká [74] (p. 4) described the problematic cooperation between social workers from NGOs and municipal child protection departments as follows: "From the narratives of the child protection professionals, the ever-present rivalry between the state and non-governmental sectors and social workers is obvious, and represents a significant split in the profession. However, different organisational settings, employers, approaches to work with clients, and funding resources, all make the state and non-governmental social workers establish different kinds of relationships with the state authorities, including municipal authorities and the MoLSA".

The starting point for any intervention of a child protection authority within this model is the assessment of the child and his or her family situation $[75,76]$. The quality assessment is considered a key to effective intervention and to reducing the risk of endangering children. Therefore, a methodology for assessing children's needs was prepared in 2014 [75], intended to offer an instrument for social workers to make it easier for them to put this method into practice. In the same year, MoLSA [77] published a manual for the implementation of evaluation related to the transformation of the welfare system for vulnerable children and families, where one of the goals of this transformation is to optimize the activities of municipal child protection departments. The methodology and legislation are thus based on casework principles, which are known for applying the tools of structured evaluation and an individual child service protection plan. According to the Decree on the Implementation of Certain Provisions of the Act on the Social and Legal Protection of Children 473/2012 Coll. in Section 1, the evaluation should not only focus on the child's situation, but also on child's family, including more extended family ties. The evaluation focuses mainly on the identification of risks and risk factors. It serves to determine the current degree of risk to the child in order to determine the speed, severity, and intensity of the intervention [78]. If the evaluation proves that a child is at risk, an individual protection plan is subsequently drawn up or a subsequent comprehensive evaluation is carried out [75]. Navrátilová [79] added that CZE has a tradition of creating tools for assessment, especially in the area of developmental needs of the child; the critical question remains to what extent these tools have been put into practice and to what extent they remain only textbook instructions.

In this model, the area of child protection is often associated with addressing poverty and social exclusion of families [62,68,80-82]. Since approximately 2014, increased attention has been paid to the housing issue. The urgency of the housing problem was confirmed by the research carried out by Gojová et al. [82], Macela [83], and Vávrová et al. [84]. The authors all agreed that the life situation that makes minors "homeless", residing in shelters, hostels, or temporary housing in segregated areas has an impact not only on the formation of their identity and patterns of behavior, but also on their health, and they demanded system solutions, such as the adoption of a law on social housing.

If it is not possible to provide care for a child by the child's biological family, it is appealed to replace institutional care with substitute family care and to return a child to his or her own family. 
Policies aimed at deinstitutionalization of care for vulnerable children have started to be gradually pursued, with substitute family care becoming the state's preferred option [81]. In 2012, the Czech government adopted the National Strategy for the Protection of Children's Rights, which includes deinstitutionalization of the welfare system for vulnerable children, thus following the European trend of reducing the number of institutional facilities $[85,86]$.

The used possibilities for achieving integration and fighting social exclusion are gradually being questioned. Social work has been criticized for failing to efficiently fight poverty and the threat of poverty [82]. Social workers play a very weak role in promoting systemic change in this area. Despite efforts and implementation of various services, the degree of integration of socially disadvantaged children is considered low [80]. Macela [87] noted that, although prohibited by law, socio-demographic analysis has clearly shown a direct link between poverty and the placement of children into institutional or (in a better solution) substitute family care. Fučík and Janků [81] focused on a specific area of substitute family care ensured by children's relatives, who were themselves socially excluded. In their view, this type of substitute family care is failing, because it should not only serve as an option for securing children, but also must be part of the fight against poverty, social exclusion, and not contribute to their intergenerational reproduction. However, social and legal protection also fails in the more "traditional" area of its activities. There is a growing record of abused, mistreated, and neglected children [65,76,88]. In 2010, 5787 cases were recorded, while in 2016 there were 9416 cases, which was an increase by almost 63\% [89,90]. The system inefficiency is associated with a lack of different social work services [74], a lack of field work, and time for systematic work with vulnerable families or for preventive activities [91].

\subsection{A Child and Child's Family as a Subject}

Topinka [73] criticized a dominant view of families and children as primarily "being at risk" in child protection practice, which narrows space for a more broadly defined, and therefore more inclusive, concept of the target group and lacks an orientation toward supporting ordinary families and children and producing inclusive mechanisms that support family functions as a whole. Divoká [74] expanded on criticism of the situation, stating that social and legal child protection professionals deal only with urgent issues of children and families, whereas there is a much greater need for various social work services. Jílková [92] recommended putting more emphasis on prevention than on solving already existing problems; expanding activities focused on assets, resources, and positive potential of clients; supporting active and independent approaches to problems in clients; working with all family members; and systematically involving the wider social environment into solving the family life situation (relatives, organizations, institutions, etc.). Vaško [70] noted that social workers try to solve problems for their clients and do not take into account a potential of families. Similarly, Punová [93] criticized "risk-focused strategies", while positively evaluating "asset-focused strategies" aimed at increasing the scope or quality of resources and access to them as well as "process-focused strategies" aimed at mobilizing or improving adaptation systems. In this case, the effort goes beyond simply eliminating risk or increasing assets; instead, we try to influence processes that can change an individual's life. At the same time, however, the author emphasized nonexistence of research of this topic in the Czech environment. She noted that the only available research is from a psychological perspective. There is a complete lack of research based on the interventions and experiences of social workers, which are common abroad.

Glumbíková et al. [76] added that in recent years, it has become apparent that the state has shown an effort to reduce the controlling role of the social and legal protection authority and to build it more on prevention and social work values. The need for a multidisciplinary approach, teamwork, and the trend of transferring state responsibility to NGOs was emphasized, forcing child protection departments to review their own positions [74]. Jůzová Kotalová [94] stated that the role of the child protection department newly tends to be in the coordination of casework with child and family. However, there are pitfalls associated with an unclear definition of the roles of social workers between 
controlling bodies ensuring control on the one hand (with relatively large potential power implications for family systems) as a totally legitimate tool for protecting vulnerable children, and on the other hand bodies that are supposed to, based on mutual trust, support failing family systems, while developing or maintaining their parenting competencies [95].

In CZE, we can observe the emphasis on working with the family as a whole, for example, in connection with the adoption of the SLP Act in 2013, which underlined every child's right to grow up in their biological family by establishing the obligation to assess the child's situation, develop an individual child protection plan, and implement case-study conferences. At the same time, the amendment introduced the obligation for all bodies responsible for the social and legal protection of children to comply with the Quality Standards for the Social and Legal Protection of Children.

The proper functioning of the family system and the involvement of the extended family are increasingly emphasized. There is an appeal for prevention and support of the family potential in the context of the strengths of families and their support in their natural environment [70]. In this context, some new methods of work have emerged in the professional discussion, such as family conferences [94] or the method of family circles [96]. The method of family circles and family conferences strive to strengthen the competencies of family members to deal with adverse life situations, thus making them less dependent on a social welfare system. The main principle is to accept the family as an expert on the arisen situation. An integral part of these methods is the participation of children in decision-making processes. The results of the research showed that in almost half of the cases, parents were surprised by the views and needs of their children [96].

Together with a demand to support the functioning of the family system, there have also been demands for the involvement of fathers and strengthening of father's role as well as the involvement of children $[97,98]$.

In connection with this trend, the complexity of the situations that social workers have to deal with, is growing. There is a range of options for coping with the situation, including strengthening of participatory decision-making, which encourages client activity, seeking solutions, and building skills and competencies [76,80]. Jůzová Kotalová [94] emphasized that a child assessment should include finding out about the wishes not only of parents but also of children. Krchňavá [80] pointed out that there is a lack of education and training developing decision sharing and encouraging of client participation in the decision-making process. According to her, client participation takes place mostly on an intuitive level, and there is a lack of self-reflection on the question of whether clients are sufficiently informed about the possibility to participate in decision-making, especially in areas that are perceived by social workers as their domain (rules and client rights). In this situation, Řezáć [99] demanded to limit space for social workers and saw the solution in overall standardization.

However, such a system places high demands on ensuring an adequate range of services. Macela [87] pointed out that suitable services are not available for some children and that individual subsystems transfer the child between one another without being able to help the child effectively. There is no clear responsibility resulting for public bodies in this area. Topinka [73] saw as a rational starting point system unification and partial decentralization and defining of a minimum network of services for families with children, which should be available in each region or city district. Social work with families is a key element of the system.

\subsection{A Child as a Subject of Protection}

According to Vysloužilová and Navrátil [97], even in the Czech context, there has been a gradual shift in social policies and the focus of social work towards prioritizing the needs of the child over the needs of the whole family. The child's welfare comes to the fore. The authors commented on this situation rather critically and drew attention to the risks of prioritizing the needs of the child over the needs of the whole family. One of them is the increase of individualism and the weakening of family ties, which are also a source of solution to the child's situation. Despite this trend, Czech practice is characterized by shortcomings in the implementation of the Convention, especially in the child's right 
to express his or her views and the child's right to receive all required information. In 2008, the Code of Civil Procedure was amended, regulating the court's respect for the child's opinion. In the past, the law gave the opportunity to ascertain the child's opinion through his or her guardian. However, many courts maintain this practice. During interviews with parents and on-site visits in facilities, no experience was found with ascertainment of the child's opinion [91]. Chrenková et al. [56] found that a degree of involvement of minors in court proceedings concerning their upbringing is in conflict with applicable legislation, because, according to Act No. 89/2012 Coll., all children over the age of 12 should be heard, but the analysis shows that a relatively high percentage of children over the age of $12(25 \%)$ were not heard or questioned. This confirms the rigid practice of the Czech judiciary in the area of decision-making on the custody of minors. According to Navrátilová [100], the reason is that many workers still consider a child more of an object of protection, and do not feel competent to have a sensitive conversation with a child. Vítková [65] and Chrenková et al. [56] accentuated the need for developing the competence of social workers to flexibly adapt interventions to children's perceptions of a meaningful world and to adapt communication to a child's age and the conditions in which a child is growing up.

The whole system of assistance has also been criticized. It needs to be transformed to meet the needs and real interests of children at risk [95]. In this context, Macela [87] criticized the fragmentation of the system, which-regardless of children's real needs—is divided into many subsystems of management and funding, legal regulations, and levels of public administration, while lacking a range of services to address the situation of families with children. Topinka [73] believed that the current system does not place sufficient emphasis on ensuring the child's development in his or her natural environment or substitute family environment, while underestimating the importance of the child's natural relationships and ties to close persons and family. Topinka further stated that the child's opinion is still not sufficiently taken into account in decision-making processes (often the child's opinion is not even heard), and there are no mechanisms for involving children and youth in decision-making processes at all levels. As a result, more favorable procedures and methods of work are not used to a child's benefit; the child often finds himself or herself in the most expensive and least beneficial form of care (institutional) - there is a magnet effect, a child who ends up in one of the segments is "caught" by it and may find it difficult to move somewhere else.

Despite this criticism, there appears to be a range of activities that try to bring the child to the center of attention. With the approval of the National Strategy for the Protection of Children's Rights, the Czech Government undertook to create a functional system by 2018, ensuring a thorough protection of all children's rights and the fulfilment of their needs [73]. The author argues that transition from a narrowly defined "social and legal protection of children" to an integrated "child protection system" begins with a definition of the rights of children and families with children. One of the areas in question is the method of assessing the child's best interest, which, according to Navrátilová [100], shows a number of ambiguities.

\section{Discussion}

\subsection{Identified Child Protection Models and Their Development over Time}

The analysis helped us to identify four basic models applied in the social and legal protection of children in the CZE. The analysis shows that each of the models is based on a different concept of the unit of protection (child vs. family), understanding of its role (object vs. subject), and reasons for protection. This understanding provides a basis for the construction of protection objectives, procedures, and interventions used. Each of the models raises typical discussion topics. The models can also be understood as certain developmental stages of child protection approaches in CZE.

Figure 1 tries to fit each model into the time frame and identify a path of child protection in CZE. The first phase can be referred to as the pretransformation phase, which began before the fall of communism and continued throughout the 1990s. The criticism of this state was an impulse for 
the transformation phase to begin, characterized by the model of a child and a family as the object of child protection dominated. In the implementation phase, the child as an object model was definitely abandoned. Although the concept of a vulnerable child and his family as an object is still strongly present in practice, as evidenced by the barriers mentioned below, a critical reflection of practice is growing in professional discourse and participatory approaches have started to be preferred [79]. The beginnings of the conception of a child as a subject of protection can be dated back to 2006, when the transformation of the system of care for vulnerable children and their families began to be systematically addressed in the CZE. The transformation was based on the adopted Convention and the National Strategy for the Protection of the Rights of the Child- "The Right to Childhood", which was approved by the Czech government in 2012. The supra-ministerial strategy outlines four key areas of child protection, namely child participation, elimination of discrimination and unequal treatment of children and youth, the right to family care, and ensuring the quality life for children and families [101]. The period associated with strategy approval can be considered the beginning of the implementation phase.

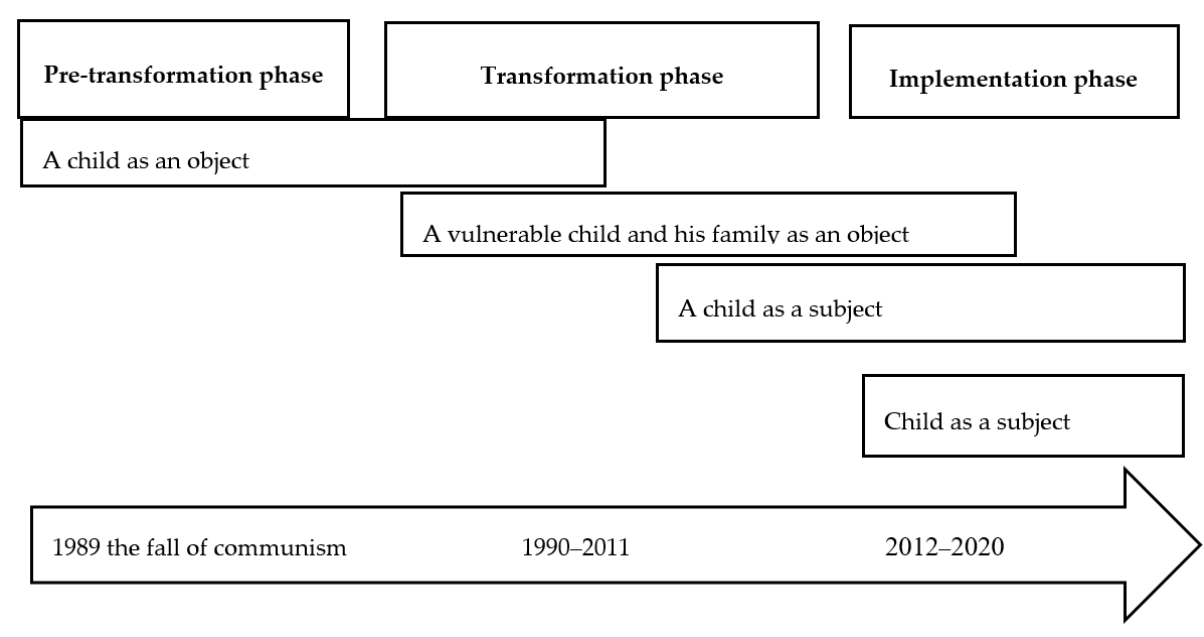

Figure 1. Development of child protection models in Czech Republic (CZE) over time.

The analyzed texts show that the area of interest and goals of child protection are still understood variably, as they are based on different approaches. Apart from references to current legislation, the authors do not agree on the understanding of a child, and his or her role and rights throughout the process. Even some of the authors of the texts that were included in the analysis questioned the orientation of the whole system to the needs and interests of children.

\subsection{Barriers to Orientation to the Child's Needs and Perception of a Child as a Subject}

Although tendencies from social exclusion to child-inclusive policies [102] emphasizing the participation of children and taking into consideration child perspectives [103], as well as child-centered orientations of the system [18], prevail in the European debate, we have identified a few key barriers to development of this approach in CZE. The barriers include fragmentation of the system, low skills and competencies of social workers, and the absence of evidence-based and informed-based practice.

\subsubsection{System Fragmentation}

Orientation to the child's needs is complicated by the system state, which is extensive, complex, complicated, and divided into several parts that are not interconnected and follow their own logics, different goals, rules, and also methods of working. This develops into complicated relationships, as well as putting the interests of children and families on the periphery, who tend to be cast into a more passive client role. According to Topinka [73], the main problem is unclear competencies and responsibilities of participants. Individual components of the system fall under the responsibility of 
different ministries and intertwine with different management approaches, approaches to rights and needs of the child, and financing. The system divided into several ministries does not take in to account the needs of children; the relevant part focuses only on a partial area in the child's life. According to the author, analysis of the service network for families and children identified key moments of the unsatisfactory current state of the system-lack of experts in the field, lengthy handling of issues, impossibility to obtain all necessary information about clients, unwillingness of other authorities to cooperate, and insufficient service coverage. Topinka further claimed that the court practice is, in many cases, lengthy and the partnership approach in cases of children at risk does not work as in other European countries. The author added that a basic tool for quality monitoring, which is quality standards, is used inconsistently and only in some parts of the system. According to him, the question is the creation of a control and monitoring mechanism, which will be independent of the system of protection of children's rights and will be able to focus on (client) protection without any possible conflict of interests.

\subsubsection{Weaknesses in the Training of Social Workers}

Social workers in the area of social and legal protection of children are expected to be able to work in an (a) uncertain, (b) complex, and (c) managerially tuned work environment [76]. A diversity of child protection concepts is present not only in professional discussion and practice, but also in the education system. In the analyzed texts, the authors repeatedly pointed out the shortcomings in education and training of future social workers. In particular, it is a low ability to support the participation of clients in the decision-making process and specifically conducting an interview with the child. Navrátilová [79] considered the insufficient qualification of Czech social workers as one of the key factors that influence the assessment of the family's situation and its form.

According to Šiška and Latimier [91], a topic of social and legal protection is missing in lifelong learning for employees of any social and legal child protection authority, which would help them to formulate the best interests of the child. According to Krchňavá [80], client participation takes place mainly on an intuitive level, and there is a lack of self-reflection of social workers on whether clients are sufficiently informed about the possibility to participate in decision-making. Vávrová and Vaculíková [84] added that reform of the vulnerable child welfare system in CZE will also affect the system of international adoption, which is an integral part. However, it is often neglected, and thus social workers should also be trained in this area within their education.

\subsubsection{Absence of Information-Based and Evidence-Based Practice}

Only four texts (published in 2010, 2019, 2019, 2020) were identified in the analyzed literature, which brought research results focused on the impact of interventions of social and legal protection of children on children themselves. At the same time, "practice informed by knowledge of the latest theory and research" and "the measure of the success of child protection" is a prerequisite for an effective child protection system" [18] (p.23). We can observe a gradual change in this area. The Rapid Rehousing methodology for families with children [104], which originated as part of a single-site field trial of the effectiveness of Housing First in the CZE with a randomized 150 participating homeless families between 2016-2018, demonstrating the positive effects of housing stabilization on children [105]. Vávrová [106] carried out research on self-regulation of children living in institutional care, which, however, was not published in Czech-language professional journals. Research on social adjustment of homeless children [107], within which this analysis was carried out, also seeks to support child-centered practice.

\section{Conclusions}

Although the above-mentioned professional texts mainly pointed out shortcomings in social work practice, the reason for optimism may be the fact that MoLSA, in the role of an umbrella body of state administration and an author of all methodologies, is aware of shortcomings and, in the form of 
projects focusing on various topics of social work with families, works to improve competences and knowledge and to also support, in particular, local cooperation between state administration bodies, NGOs providing socio-activation services for families with children, and other traditional entities such as schools and health care facilities. Since October 2018, the project Support for Systemic Changes in the Care and Custody of At-Risk Children, Young People, and Families in CZE has been underway, focusing on supporting regions in fulfilling children's right to family life. The project will run until May 2022 (MoLSA, 2020). In 2016-2020, the Office for the International Legal Protection of Children of the CZE implemented the project Rights and Participation of the Child in the Agendas of the Office for the International Legal Protection of Children. One of the project activities included organization of eight conferences, where the professional public was informed of changes and successes in the area of strengthening children's participation rights. The conference output is professional proceedings. It can be concluded that the implementation phase we find ourselves in in the CZE does not take place in the form of a "revolution", but rather an "evolution", that is, a slow and gradual introduction and adoption of social work focused on the needs of children. The analyzed texts described several examples of good practice from international contexts that were a source of inspiration for the Czech practice. Those examples included the UK practice (Youth Offending Teams Project), family conferences from New Zealand and applied in many European countries, Big Brothers Big Sisters projects from the USA, and the Eigen Kracht approach from the Netherlands. The strong inspiration and influence, mainly from other EU child protection politics, was declared in many analyzed texts and is necessary for the sustainability of the path towards more child centered policies in the CZE.

Author Contributions: Conceptualization, A.G., B.G., and K.C.; methodology, A.G.; analysis, A.G., B.G., K.C., and M.C.; resources, B.G. and K.C., writing-original draft preparation, A.G. All authors have read and agreed to the published version of the manuscript.

Funding: The article was created within a grant project GA CR No. 18-10233S Social Adjustment of Homeless Children with Domestic Violence Experience in the Territory of the City of Ostrava.

Conflicts of Interest: The authors declare no conflict of interest.

\section{References}

1. Nosál, I. Participace dětí na vlastním osudu-spolupracující a na řešení zaměřené způsoby práce s dětmi v náhradní péči. In Participace a nové př́stupy k práci s ohroženými dětmi a rodinami; Nosál, I., Čechová, I., Eds.; Česko-Britská o.p.s.: Brno, Czech Republic, 2014; pp. 14-37.

2. Parton, N. Challenges to practice and knowledge in child welfare social work: From the "social" to the “informational"? Child. Youth Serv. Rev. 2009, 31, 715-721. [CrossRef]

3. Spratt, T. The influence of child protection orientation on child welfare practice. Br. J. Soc. Work 2001, 31, 933-954. [CrossRef]

4. Gilligan, R. Adversity, resilience, and young people: The protective value of positive school and spare time experiences. Child. Soc. 2000, 14, 37-47. [CrossRef]

5. Gardner, R. Supporting Families: Child Protection in the Community; Wiley: Chichester, UK, 2003.

6. Stevenson, O. Neglected Children and Their Families; Blackwell Publishing: Oxford, UK, 2007.

7. Roose, R.; Roets, G.; Schiettecat, T. Implementing a strengths perspective in child welfare and protection: A challenge not to be taken lightly. Eur. J. Soc. Work 2012, 17, 3-17. [CrossRef]

8. Devaney, C.; McGregor, C.; Cassidy, A. Early implementation of a family-centred practice model in child welfare: Findings from an Irish case study. Practice 2017, 29, 331-345. [CrossRef]

9. Pösö, T. Combatting child abuse in Finland: From Family to Child-Centered Orientation. In Child Protection Systems: International Trends and Orientations; Gilbert, N., Parton, N., Skivenes, M., Eds.; Oxford University Press: New York, NY, USA, 2011; pp. 112-130.

10. D'Cruz, H.; Stagnitti, K. Reconstructing child welfare through participatory and child-centered professional practice: A conceptual approach. Child Fam. Soc. Work 2008, 13, 156-165.

11. Toros, K.; Tiko, A.; Saia, K. Child-centered approaches in the context of the assessment of children in need: Reflections of child protection workers in Estonia. Child. Youth Serv. Rev. 2013, 35, 1015-1022. [CrossRef] 
12. Pinkerton, J.; Dolan, P. Family support, social capital, resilience and adolescent coping. Child Fam. Soc. Work 2007, 12, 219-228. [CrossRef]

13. Skivenes, M. Norway: Toward a Child-Centric Perspective. In Child Protection Systems: International Trends and Orientations; Gilbert, N., Parton, N., Skivenes, M., Eds.; Oxford University Press: New York, NY, USA, 2011; pp. 154-180.

14. Spratt, T.; Nett, J.; Bromfield, L.; Hietamäki, J.; Kindler, H.; Ponnert, L. Child protection in Europe: Development of an international cross-comparison model to inform national policies and practices. Br. J. Soc. Work 2015, 45, 1508-1525. [CrossRef]

15. Palmer, E. Trafficked children and child protection systems in the European Union. Eur. J. Soc. Work 2019, 22, 551-562. [CrossRef]

16. Callahan, M. The Administrative and Practice Context: Perspectives from the Front Line. In Rethinking Child Welfare in Canada; Wharf, B., Ed.; McClelland and Stewart: Toronto, ON, Canada, 1993.

17. Parton, N. Safeguarding Childhood: Early Intervention and Surveillance in a Late Modern Society; Palgrave Macmillan: Basingstoke, UK, 2006.

18. Munro, E. The Munro Review of Child Protection: Final Report, a Child-Centred System; The Stationery Office: London, UK, 2011.

19. Prilleltensky, I.; Prilleltensky, O. Towards a critical health psychology practice. J. Health Psychol. 2003, 8, 197-210. [CrossRef] [PubMed]

20. Gerson, J. Hope Springs Maternal: Homeless Mothers Talk About Making Sense of Adversity; Gordian Knot Books: New York, NY, USA, 2007.

21. Swick, K.J.; Williams, R. The voices of single parent mothers who are homeless: Implications for early childhood professionals. Early Child. Educ. J. 2010, 38, 49-55. [CrossRef]

22. Skott, B.P. Motherhood Mystique. In Encyclopedia of Family Studies; Shehan, C.L., Ed.; Wiley-Blackwell: London, UK, 2016.

23. Warshak, R.A. Custody Revolution: Father Custody and the Motherhood Mystique; Simon \& Schuster: New York, NY, USA, 1992.

24. Sinai-Glazer, H.; Peled, E. The perceptions of motherhood among family social workers in social services departments in Israel. Br. J. Soc. Work 2017, 47, 1482-1499. [CrossRef]

25. Swift, K. Manufacturing 'Bad Mothers': A Critical Perspective on Child Neglect, 2nd ed.; University of Toronto Press: Toronto, ON, Canada, 1995.

26. Ferguson, H. Social work, individualization and life politics. Br. J. Soc. Work 2001, 31, 41-55. [CrossRef]

27. Scourfield, J. Constructing men in child protection work. Men Masc. 2001, 4, 70-89. [CrossRef]

28. Ewart-Boyle, S.; Manktelow, R.; McColgan, M. Social work and the shadow father: Lessons for engaging fathers in Northern Ireland. Child Fam. Soc. Work 2015, 20, 470-479. [CrossRef]

29. D'Cruz, H. Constructing the identities of 'responsible mothers, invisible men'in child protection practice. Sociol. Res. Online 2002, 78, 1-19.

30. Featherstone, B.; Gupta, A.; Morris, K.; Warner, J. Let's stop feeding the risk monster: Towards a social model of 'child protection'. Fam. Relatsh. Soc. 2018, 7, 7-22. [CrossRef]

31. Buckley, H.; Carr, N.; Whelan, S. 'Like walking on eggshells': Service user views and expectations of the child protection system. Child Fam. Soc. Work 2011, 16, 101-110. [CrossRef]

32. Jackson, S.; Kelly, L.; Leslie, B. Parental participation in statutory child protection intervention in Scotland. Br. J. Soc. Work 2016, 47, 1-19. [CrossRef]

33. D'Cruz, H. Constructing Meanings and Identities in Child Protection Practice; Tertiary Press: Croydon, UK, 2004.

34. Parton, N.; O’Byrne, P. Constructive Social Work: Towards a New Practice; Macmillan: London, UK, 2000.

35. Ruch, G. Relationship-based practice and reflective practice: Holistic approaches to contemporary child care social work. Child Fam. Soc. Work 2005, 10, 111-123. [CrossRef]

36. Fraser, S.; Lewis, V.; Ding, S.; Kellett, M.; Robinson, C. Doing Research with Children and Young People; Sage: London, UK, 2004.

37. Welbourne, P.; Dixon, J. Child protection and welfare: Cultures, policies, and practices. Eur. J. Soc. Work 2016, 17, 827-840. [CrossRef]

38. Pösö, T.; Skivenes, M.; Hestbæk, A. Child protection systems within the Danish, Finish and Norwegian welfare states-time for a child centric approach? Eur. J. Soc. Work 2014, 17, 475-490. [CrossRef] 
39. Race, T.; O'Keefe, R. Child-Centered Practice; Macmillan Education: London, UK, 2017.

40. Bijleveld, G.G.; Dedding, C.W.M.; Bunders-Aelen, J.F.F. Chidren's and young people's participation within child welfare and child protection services: A state-of-the art review. Child Fam. Soc. Work 2013, 20, 129-138. [CrossRef]

41. Seim, S.; Slettebø, T. Challenges of participation in child welfare. Eur. J. Soc. Work 2017, 20, 882-893. [CrossRef]

42. Špiláčková, M. Soziale Arbeit im Sozialismus: Ein Beispiel aus der Tschechoslowakei (1968-1989); Springer VS: Wiesbaden, Germany, 2014; pp. 67-83.

43. Radvanová, S. Ubližování dětem-nebezpečná rodina. In Pocta Otovi Novotnému k 80. Narozeninám, 1st ed.; Vanduchová, M., Gřivna, T., Eds.; ASPI: Praha, Česká Republika, 2008; p. 270.

44. Hodgkin, R.; Newell, P. Implementation Handbook for the Convention on the Rights of the Child; UNICEF: Geneva, Switzerland; New York, NY, USA, 2007; pp. 102-460.

45. Freeman, M. The Best Interests of the Child. In A Commentary on the United Nations Convention on the Rights of the Child; Alen, A., Lanotte, J.V., Eds.; Martinus Nijhoff Publishers: Leiden, The Netherlands, 2007; p. 80.

46. The Supreme Court of the Czech Republic. Available online: http://www.nsoud.cz/ (accessed on 19 September 2020).

47. Zuklínová, M. Cui bono? Bezvýjimečně ve prospěch tohoto dítěte! Zamyšlení nad péčí o dítě. Právník 2015, 154, 97-124.

48. Právo na Dětství. Available online: http://www.pravonadetstvi.cz/ (accessed on 19 September 2020).

49. Kornel, M. Některé problematické aspekty principu nejlepšího zájmu dítěte. Právní rozhl. 2013, 3, 88-93.

50. Act No. 359/1999 Coll., On the Social and Legal Protection of Children. Available online: https://www. zakonyprolidi.cz/cs/1999-359 (accessed on 19 September 2020).

51. Westphalová, L.; Holá, L. Zapojování dětí do rozhodování ve věcech, které se jich týkají, v kontextu rodinné mediace. Právní rozhl. 2019, 13/14, 70-80.

52. 54/2001 Collections of the Ministry of Justice. Communication from the Ministry of Foreign Affairs on the adoption of the European Convention on the Exercise of Children's Rights. Available online: https://www.zakonyprolidi.cz/ms/2001-54 (accessed on 19 September 2020).

53. Council Regulation (EC) No 2201/2003 of 27 November 2003 Concerning Jurisdiction and the Recognition and Enforcement of Judgments in Matrimonial Matters and the Matters of Parental Responsibility. Available online: https:/eur-lex.europa.eu/legal-content/CS/ALL/?uri=CELEX\%3A32003R2201 (accessed on 19 September 2020).

54. Ministry of Justice. Available online: http://obcanskyzakonik.justice.cz/index.php/home/zakony-astanoviska/preklady/english (accessed on 19 September 2020).

55. Kapitán, Z. Participační práva dětí v praxi českého systému právní ochrany dětí, zejména justice. In Společnost Přátelská k Dětem v Obtižích; Jílek, D., Čechová, I., Eds.; Česko-Britská o.p.s.: Brno, Česká Republika, 2016; pp. 85-94.

56. Chrenková, M.; Cilečková, K.; Vaňharová, A. The participation of minors in the proceedings regarding thier upbringing and maintenance. Sociální Práce/Sociálna Práca 2019, 19, 34-47.

57. Marková, I.; Šimáčková, K. Jak se téma justice vstřícné k dětem odráží v procesních postupech vrcholných soudů. In Porceedings of Zjišt'ování Názoru Dítěte v Soudní Praxi, Brno, Czech Republic, 17-18 May 2017; Brzobohatý, R., Ed.; Úřad pro Mezinárodně Právní Ochranu Dětí: Brno, Czech Republic, 2018; pp. 70-80.

58. Braun, V.; Clarke, V. Using thematic analysis in psychology. Qual. Res. Psychol. 2006, 3, 77-101. [CrossRef]

59. Slavík, J.; Chrz, V.; Štech, S. Tvorba Jako Způsob Poznávání; Karolinum: Praha, Czech Republic, 2013.

60. Šporcrová, I.; Winkler, J. Potřeby dítěte a náhradní výchovná péče. Sociální Práce/Sociálna Práca 2003, 21, 54-69.

61. Zoubková, P. Individualizace péče ve zdravotnických zařízeních pro děti do tří let a faktory organizační kultury, které ji mohou ovlivnit. Sociální Práce/Sociálna Práca 2008, 8, 100-111.

62. Knausová, I. Teorie a Praxe Sanace Rodiny v českém Prostředí-Kvalitativní sonda do terénní práce s ohroženou rodinou v současnosti. Sociální Práce/Sociálna Práca 2011, 11, 68-73.

63. Hauková, Z. Umíst'ování dětí do náhradní péče o dítě. Sociální Práce/Sociálna Práca 2005, 5, 107-123.

64. Dobešová, B. Mateřství soukromé i veřejné-př́ípad instituce SOS dětské vesničky. Sociální Práce/Sociálna Práca 2010, 10, 118-126.

65. Vítková, J. Možnosti sociální práce se sexuálně zneužívaným dítětem. Sociální Práce/Sociálna Práca 2003, 3, 70-83. 
66. Bechyňová, V.; Konvičková, M. Sanace Rodiny-Rociální Práce s Dysfunkčními Rodinami; Portál: Praha, Czech Republic, 2008.

67. Šišláková, M. Podmínky výchovy v romských sociálně vyloučených rodinách. Sociální Práce/Sociálna Práca 2005, 5, 68-84.

68. Krátká, K. Integrace Romů z pohledu náhradní rodinné péče. Sociální Práce/Sociálna Práca 2003, 3, 119-126.

69. Foltová, L. Posouzení životní situace adolescentů s psychickými poruchami. Sociální Práce/Sociálna Práca 2010, 10, 101-110.

70. Vaško, M. Pojetí podpory potenciálu rodin v nesnázích. Sociální Práce/Sociálna Práca 2020, 20, 97-116.

71. Vaško, M. Role sociálních pracovníků $\mathrm{z}$ hlediska přístupů rodičů $\mathrm{k}$ léčbě enurézy dětí. Sociální Práce/Sociálna Práca 2018, 18, 105-122.

72. Janebová, R. „Ale nikomu to neříkejte ... “ aneb dilema mezi sdělováním informací a mlčenlivostí v oblasti sociálně-právní ochrany dětí. Sociální Práce/Sociálna Práca 2010, 10, 88-99.

73. Topinka, D. Optimalizace řízení systému ochrany práv dětí a péče o ohrožené děti. Sociální Práce/Sociálna Práca 2015, 15, 47-51.

74. Divoká, L. Professionalization of Child Protection in the Czech Republic from the Perspective of Sociological Theories. Sociální Práce/Sociálna Práca 2017, 17, 30-47.

75. Racek, J.; Solařová, H.; Svobodová, A. Vyhodnocování Potřeb Dětí; Lumos: Praha, Czech Republic, 2014.

76. Glumbíková, K.; Vávrová, S.; Nedělníková, D. Optiky posuzování v agendě sociálně-právní ochrany dětí. Sociální Práce/Sociálna Práca 2018, 18, 78-88.

77. MoLSA. Vyhodnocování Situace dítěte a Rodiny a Tvorby Individuálního Plánu Ochrany Dítěte; MoLSA: Praha, Czech Republic, 2014; Available online: http://www.pravonadetstvi.cz/files/files/Manualimplementace-vyhodnocovani-situace-a-IPOD_MPSV.pdf (accessed on 19 September 2020).

78. Pemová, T.; Ptáček, R. Zanedbávání Dětí. Př́činy, Dưsledky a Možnosti Hodnocení; Grada: Praha, Czech Republic, 2016.

79. Navrátilová, J. Proces posouzení životní situace jako zdroje ohrožení dítěte (faktory ovlivňující posouzení ohrožených dětí). Sociální Práce/Sociálna Práca 2011, 11, 40-55.

80. Krchňavá, A. The participatory approach in low-threshold centres for children and youth. Sociální Práce/Sociálna Práca 2014, 14, 46-57.

81. Fučík, P.; Janků, K. Paradoxy a výzvy náhradní rodinné péče vykonávané příbuznými v sociálně vyloučené lokalitě. Sociální Práce/Sociálna Práca 2019, 19, 44-61.

82. Gojová, A.; Gojová, V.; Lindovská, E.; Špiláčková, M.; Vondroušová, K. Způsoby zvládání chudoby a ohrožení chudobou rodinami s nezletilými dětmi. Sociální Práce/Sociálna Práca 2014, 14, 44-60.

83. Macela, M. Reforma systému ochrany práv dětí a péče o ohrožené děti. Sociální Práce/Sociálna Práca 2012, 12, 45-48.

84. Vávrová, S.; Vaculíková, J. Attitudes of the Czech public towards international adoption of minors. Sociální Práce/Sociálna Práca 2019, 19, 84-93.

85. MoLSA. The National Strategy for the Protection of Children's Rights and the Action Plan for the Fulfillment of the National Strategy. Available online: https://www.mpsv.cz/narodni-strategie-ochrany-prav-deti-aakcni-plan-k-naplneni-narodni-strategie (accessed on 19 September 2020).

86. Sodomková, L.; Šerek, J.; Juhová, D. Občanské postoje a participace u adolescentů žijících v dětských domovech. Sociální Práce/Sociálna Práca 2018, 18, 126-143.

87. Macela, M. Reforma péče o ohrožené děti v České republice. Závěry nejnovějších výzkumů a jejich dopad do praxe. Sociální Práce/Sociálna Práca 2015, 15, 7-11.

88. Víravová, J. Souvislosti a fakta o týraných a zanedbávaných dětech z diagnostického ústavu. Sociální Práce/Sociálna Práca 2015, 15, 5-27.

89. MoLSA. Statistical Yearbook of Labor and Social Affairs 2010; MoLSA: Praha, Czech Republic, 2011.

90. MoLSA. Statistical Yearbook of Labor and Social Affairs 2016; MoLSA: Praha, Czech Republic, 2017.

91. Šiška, J.; Latimier, C. Práva dětí s mentálním postižením v České republice v kontextu Úmluvy o právech dítěte OSN. Sociální Práce/Sociálna Práca 2011, 11, 105-119.

92. Jílková, A. Podporování resilience rodin prostřednictvím projektu Asistent do rodiny. Sociální Práce/Sociálna Práca 2012, 12, 104-114.

93. Punová, M. Konceptuální vymezení resilienční sociální práce s mládeží. Sociální Práce/Sociálna Práca 2012, 12, 67-75. 
94. Jůzová Kotalová, K. Nástroje sociálně-právní ochrany dětí v praxi. Sociální Práce/Sociálna Práca 2015, 15, $23-27$.

95. Rychlík, D. Systém ochrany ohrožených dětí v ČR aneb v procesu měnícího se paradigmatu. Sociální Práce/Sociálna Práca 2015, 15, 3-6.

96. Vlčková, T. Rodinné kruhy na Vysočině. Sociální Práce/Sociálna Práca 2016, 16.

97. Vysloužilová, A.; Navrátil, P. Individualizace v sociální práci s rodinou-obviňování obětí. Sociální Práce/Sociálna Práca 2019, 19, 142-157.

98. Gřundělová, B. Faktory ovlivňující zapojení otců v sociální práci s rodinou. Sociální Práce/Sociálna Práca 2020, 20,79-98.

99. Řezáč, K. Dopady diskurzů sociální práce na doprovázející organizace pěstounské péče. Sociální Práce/Sociálna Práca 2016, 16, 86-96.

100. Navrátilová, J. Využití capability přístupu při posouzení dětského well-beingu. Sociální Práce/Sociálna Práca 2018, 18, 65-77.

101. Šíp, M.; Hájková, M. Vzdělávání Jako Cilený Rozvoj Kompetencí. Soubor Doporučení pro Optimalizaci Systému Vzdělávání Pracovniku OSPOD; MPSV: Praha, Czech Republic, 2019.

102. Gal, T.; Duramy, B.F. Enhancing Capacities for Child Participation: Introduction. In International Perspectives and Empirical Findings on Child Participation: From Social Exclusion to Child-Inclusive Policies; Gal, T., Duramy, B.F., Eds.; Oxford University Press: New York, NY, USA, 2015; pp. 1-16.

103. Sommer, D.; Pramling, I.; Hundeide, K. Child Perspectives and Children's Perspectives in Theory and Practice; Springer: Dordrecht, The Netherlands, 2010.

104. Ripka, Š.; Černá, E.; Kubala, P.; Staněk, R. Pilotní Testování Rychlého Zabydlení rodin s Dětmi (Rapid Re-Housing); Ostravská Univerzita: Ostrava, Czech Republic, 2018.

105. Ripka, Š.; Černá, E.; Kubala, P.; Krčál, O.; Staněk, R. The Housing First for Families in Brno Trial Protocol: A Pragmatic Single-Site Randomized Control Trial of Housing First Intervention for Homeless Families in Brno, the Czech Republic. Eur. J. Homelessness 2018, 12, 133-150.

106. Vávrová, S. Children and Minors in Institutional Care: Research of Self-Regulation. In Procedia Social and Behavioural Sciences, Proceedings of the 5th International Conference on Education and Educational Psychology (ICEEPSY), Kyrenia, Cyprus, 22-25 October 2014; Bekirogullari, Z., Minas, M.Y., Eds.; Elsevier Science: Amsterdam, The Netherlands, 2015; Volume 171, pp. 1434-1441.

107. Vávrová, S.; Glumbíková, K.; Gojová, A. A preliminary model of the social situation of social adjustment of homeless children. In European Proceedings of Social and Behavioural Sciences, Proceedings of the 9th International Conference on Education and Educational Psychology (ICEEPSY), Athens, Greece, 2-5 October 2018; Bekirogullari, Z., Minas, M.Y., Thambusamy, R.X., Eds.; Future Acad: Nicosia, Cyprus, 2019; Volume 53, pp. 232-240.

Publisher's Note: MDPI stays neutral with regard to jurisdictional claims in published maps and institutional affiliations.

(C) 2020 by the authors. Licensee MDPI, Basel, Switzerland. This article is an open access article distributed under the terms and conditions of the Creative Commons Attribution (CC BY) license (http://creativecommons.org/licenses/by/4.0/). 